\title{
Performance of Islamic and Conventional Banks in Pakistan (2006-2011), a Comparatives Study
}

\author{
Maryam Amjad, Hafiza Tahira, Yasir Akram, M.Usman \\ (Zeeshan Arshad, M. Amer Saeed Butt) Faculty ssenisuB fO loohcS, University of Gujrat
}

\begin{abstract}
The aim of this paper was conducted to investigate the financial performance of Islamic and Conventional banks to support depositors, bank managers, shareholders, investors and regulators by providing true picture of financial position of Islamic as well conventional banks in Pakistan. The ratios often compare financial statement data with stock market trading information for publicly traded companies. Financial ratios are an important tool of economic decision-making for all businesses. It is important to choose financial ratios that are applicable to the business at hand. There are hundreds of financial ratios available, some of which apply to all businesses and some of which are industry-specific. Financial ratios were estimated from annual reports and financial statements i.e. Income statement and Balance sheet for the period of 2008 to 2011. Twelve financial ratios were estimated to measure these performances in term of profitability, liquidity, risk and solvency, capital adequacy. To determine the significance of mean differences of these ratios, Independent sample t-test and ANOVA was used between and among banks. The study concluded that Islamic banks proved to be more liquid, less risky and operationally efficient than conventional banks
\end{abstract}

Key Words: Islamic banks, conventional banks, financial performance, Annova, t-test, Pakistan

\section{Introduction;}

Islam is an inclusive way of life, which strikes the stability between the religious and the material needs of human being. One of the significant aspects in human beings life is the need for an absolute system in order to rule their life style and to ensure about all other needs such as the financial management system. Every human being has a right to live his life by his own choice. It is not compulsory that one method is suitable and acceptable for all. Some rules and systems are not providing satisfactory results to different types of the organization. (It may be due to his religious or other values). Let's take an example of two different systems. Like conventional financing system and Islamic financing system. Conventional financing system is based under the principal of capitalism and charging interest. But Islamic financing system is developed under the concept of "interest free" and fair distribution of wealth. So the system of conventional finance (charging interest) is not acceptable for Muslims because interest is prohibited in Islamic.

"O those who believe do not eat up riba doubled and redoubled" (Surah Al-i-Imran 3:130)

"Riba (interest) is very significant term in Islamic expressions showing displeasure and it refer to the instrument by which a hermit charge some amount lump sum or installments over and above his principle amount from the loanee and thus increase his wealth multiple without participating in the business process of profit and loss"( Islamic Fiqh Academy India defines)

"Any supplementary amount over the principal in a dissimilarity of loan or debt is the riba proscribed by the Holy Qur'an in several verses" (usmani, 1999 Para 242, Supreme Court of Pakistan defines)

Interest is not only one reason to discourage the religious value but social evils are also a gigantic reason like first the charging of interest on loans basically discourages the moral values and ethics secondly rich person becomes more rich and poor person become more poor due to interest. Rich people earned abnormal profit in shape of interest but poor people have nothing to invest by which he can gain profit. And the last is Another social evil of interest is unfair distribution of wealth. So Muslims have no choice expect to establish their own system. The interest is not only one reason to develop a Islamic financing system. The collapse of major institutions, which was adopted the conventional finance system is also a grand reason for introducing a new Islamic finance system. Conventional finance faced severe global crisis in some years. ", the start of the incident has been pinpointed as 9 August 2007 when bad news from French bank. Lehman Brothers was the first major bank to collapse in the credit crisis. J.P.Morgan, Lehman Brothers, Northern Rock" is also examples of credit crunch. Credit crunch means "a severe shortage of money or credit". The world economy is still suffering the crises by adopting conventional financing.

This study is an attempt to understand the financial health of conventional and Islamic finance in term of utilizing ratios. Here the question is that what is Islamic finance? What is the performance of Islamic finance in modern economy? Islamic finance system is essential goal of Islam to realize the greater justice in society. Islamic financial system may be able to prop up the justice and other values if, it satisfies at least two 
conditions. Financier should also share the risk as well as profit, secondly, equally share in equity. Islamic finance is totally based on the concept of SHARIAH (Islamic law). SHARIHA provides guidelines about religion, banking business, politics and law. Different concept of convention financing system is used in Islamic financing system in different way by SHARIA. For example Ijara (leasing), Musharaka (equity participation), Mudaraba (partnership financing), Istinaa (Commissioned Manufacture), Riba (interest). In conventional banking the term interest is used in place of Riba .Riba means "charging and prearranged additional amount on a loan extensive base on length of credit period". The concept of Islamic finance is not a new in this world. Modern birth of Islamic financing institution in early 1960's (Egypt). The practices of Islamic finance which we classify today have been activate throughout the last1500 old year, across the Muslim country and beyond. But the real high growth of institution and asset under management is developed in 1970's and 1980's. 300 Islamic financial institutions are operating more than 75 countries in 2007. Many Muslims countries like Sudan, Malaysia, Iran and Saudi Arabia and Pakistan have adopting Islamic financing system. Islamic financing is not only adopting by Muslim society. "The majority of Islamic finance or non Muslim with a growing existence of foreign investor" (price water house coppers Malaysia, 2008).

This paper covers the aspects of Islamic finance, indicate the financial health of conventional as well as Islamic finance in modern economy and provide clear representation of banks financial position to shareholders, management and investors.

\section{Primary objective}

\section{Objectives}

1) To compare the performance of Islamic and conventional banks in Pakistan. Secondary objective

(1) To identify and Indicate the financial health of conventional as well as Islamic banks.

(2) To analysis the Performance of Islamic banks in Pakistan.

\section{Literature Review}

Olga krasicka \& sylwia nowak examined the concept of Islamic and conventional financing with the prospective of capital market and banking sector. This paper contrasts conventional and Islamic financing instrument and bank in Malaysia. They found that how Islamic stock differs from conventional stock and which one is more profitable? History of developing Islamic financing is also discussed in this paper over the year and also some tax incentive is mentioned. Ratios is used in this paper as a methodology for checking the efficiency of Islamic and conventional financing and through these ratios get the result in the favor of Islamic financing system. According to the Olga krasicka and sylwia nowak (2012) overall the market share of Islamic financing sector is growing and the market is deepening. They also found that Malaysia Islamic finance had grown to the third largest market in the global Islamic finance industry and the gap between Islamic and conventional financial practices was dwindled.( Olga krasicka \& sylwia nowak, 2012)

Juan sole(2007) examined in "introducing Islamic finance into conventional financing", that the global growth rate of Islamic financing is increased 10-15 percent per annum over the last decades and the practices of Islamic growth is not only limited up to Islamic country but also in other countries where Muslims are in minority like as Japan, united kingdom. But still some financial authorities remain unfamiliar with the process by which the Islamic finance was introduced in to convention finance system. This paper focuses on the process by which Islamic banking is implanted in traditional financial systems. Drawing from the practice of several countries in which Islamic banking was introducing over a period of time, the paper delineates the main phases of the process, with the intent of underscoring the main challenges faced by supervisors and practitioners at each stage and also discusses $\mathrm{s}$ the main elements required to build a supporting financial infrastructure that conforms to Islamic principles. This paper attempts to shed some light in this system by introducing the main phases in this process. He also found the challenges that might a country faced by developing Islamic financing institutes alongside conventional institutes. (Juan sole, 2007)

Toni and Felix focused in "Islamic financing: theories, practices and insight for Nigeria" about the knowledge and different practices of Islamic financing in NIGERIA and also draw some useful insights on Islamic banking in Nigeria. Prevention of interest, low consumer lending, profit and loss sharing and high real sector investing are primary characteristics of Islamic banks. In this paper complete description of all these term like prevention of interest, low consumer lending, profit and loss sharing and high real sector investing is discussed. According to the Toni and Felix (2009) prevention of interest is the most vital attribute of Islamic banking is that it is interest-free. Islamic banks neither charge nor pay interest. Islam prohibits Muslims from taking or giving interest riba regardless of the purpose for which such loans are made and regardless of the rates at which interest is charged. Under the low consuming lending Islamic banks do not charge interest rates, consumer loans are therefore unappealing since there is no profit to be consequent in the form of interests on the loans and with the prospective of profit and loss sharing which is basic principle of Islamic financing. Under this 
condition rules of MUSHARAKA and MUDARABA should $b$ followed-up. At the last, in high real sector investing Islamic banks have been favorably twisted towards the real sectors of the various economies in which they operate. Their investment activities usually border on equity financing, trade financing and real estate investments. Future of Islamic financing is also discussed in this paper. Today, Islamic banking has not only become a dream come true, but is expanding with increasing appreciation of the link between ethics and finance. (Toni and Felix, 2009)

Ahmed and Abderrazak suggest in "Islamic finance in EUROPE: the regulatory challenge" Islamic finance has developed and spread quite appreciably all over the world. And this development brings many challenges and opportunities for industry.

In this paper Ahmed and Abderrrazak (2010) examined that the European approaches to overcome regulatory issues related to the establishment of Islamic finance institutions and the condition of Islamic products and services in these advanced and very complicated financial centers. This paper is divided in different four sections, the first section focus to provide an overview of the basic principles of IF and its latest development in Europe. In second section nature, rationale and objectives of the regulatory process and its relevance to IF is touched. Third Section summarizes the different approaches adopted worldwide in compliant IF into conventional systems, and discusses the way pursued by some European countries within the framework of those models. And at the end, fourth section some concluding remarks from the discussion and analysis carried out in the preceding sections is drawn in this section.

"The development of the industry over the years indicates that ensuring the "Islamicity" of operations is vital for standing and public assurance. The practice also reveals that the main form for ensuring that is through the slot of an internal body (SSB) or an individual (scholar) to endorse the "Islamicity" of these operations" (Ahmed \& Abderrazak, 2010)

Focused on both economic and religious need and also described about the evaluation of Islamic financing in Pakistan. In this paper it is also stated how state bank of Pakistan established new tactic for relaunch the Islamic financing. The initiative to re-introduce Islamic Banking in Pakistan was launched back in 2001 when the government decided to promote Islamic banking in a gradual manner and the aims is to building an extensive based financial system in the country to facilitate all segments of the population to access financial services. State Bank Pakistan also gave the industry the products which it was allowed to use without any change or exception. In this paper two different prospective relating to Islamic and conventional financing is described that is, conventional financing aim to meet his objectives by interest based contract and Islamic financing meet his goals by trade based contract. Agha zohaib focused in this paper on the history and growth of Islamic financing, argued about difference between interest-based financing and Islamic financing. Criteria for selection of Shariah advisor in Shariah Board is also discussed in it. The results prove that the strategy for introduction of Islamic banking in Pakistan has worked well. The growth has been impressive by any standards. (Agha zohaib khan, 2009).

Islamic financing is rising all over the world especially in Pakistan while conventional financing is astonishingly declining in the countries who are the head of capitalism and founder of the interest base system. Current world scenario shows that Islamic financing has a strong substitute of destabilized financial system. Islamic financing has recorded unbelievable growth in within a short period of time. The growing rate of Islamic financing is $20 \%$ annually. Its growth is not limited to Muslim countries but also got popular between NonMuslim countries. Many global agencies had opened the separate division in order to serve their Muslim clients. The author observed the vertical growth of Islamic and conventional financing in terms of performance and profitability. The ratio analysis technique was applied by the author to measure the performance of key indicators. By applying the ratio study concluded that all Islamic financial banks ratio are healthier and comparatively well operating. (Awan, 2009)

Some years ago conventional financing got collapse due to financial crises in the whole world. The basis $\mathrm{s}$ of collapse is interest base system, capitalism. Islamic financing is the getting higher trend in economy. It gives us the direction to run the financing on the base of free interest system, profit and loss sharing. The research examined the similarities and difference among the composition and practices of Islamic and conventional financing. The study intends to examine the characteristics of Islamic financing and its implication on large scale even in non Muslim countries also. The most important characteristics of Islamic financing are asset base financing and profit-sharing and risk bearing and a ban on uncertainty and Riba. It examined the risk and profitability among the Islamic and conventional financing in the Malaysian financing sector. In this study, commercial banks and Islamic banks are taken for empirical analysis. Statistically, it has been proved that Islamic financing system is less risky and more profitable than the conventional financing. (Kyeong et al, 2012)

Researchers discussed the Islamic financing products and interpret them in the perspective of financial intermediation theory. By comparing the Islamic financing and conventional financing he found the significant differences in the terms of business orientation, asset quality, efficiency and stability. Islamic financing are more cost effective than the conventional financing. Evidence shows that Islamic financing have higher capitalization 
and higher liquidity reserves. This blend explains the better performance of Islamic financing in the recent crises. Islamic financing gives us the solution of arising agency problems between lender and borrower, investor and manager. Researcher used the array of indicators that are taken from balance sheet and income statement. Indicators are GDP per capita that describes the economic development, GDP growth and Private Credit to GDP as measure of financial development and the three-bank concentration ratio. These indicators use to conclude the results of Islamic financing and conventional financing about the stability, cost, and asset quality. Result shows that Islamic financing business model different from conventional financing business model.

\section{(Thorsten et al, 2010)}

This research paper discussed the basic principles of Islam that gives emphasis on social justice, inclusion and sharing of resources. Islamic financing addressed the issue of financial inclusion from two directions. First one is through promoting risk sharing contracts and the second one is through specific instruments redistribution of the wealth between the societies. Both instruments complement each other to offer an inclusive approach to eradicate the poverty, and to build a healthy and lively economy. Instruments are Zakah, sadaqah, waqf, and qard-al-hassan. Study concludes that Islam is a set of instruments and unconventional approaches. If these approaches implemented in a spirit way can lead to trim down the in-equality and poverty between Muslim countries. Researcher found that financial institution developed the Islamic institution for handling the matters of zakah, qard-e-alhassan to disburse them among the needy and recycle it in an efficient and a cost effective way.( Mohieldin et al.)

The basic principle of Islamic financing is the prohibition of Riba or interest. Islamic financing is the solution of interest free financing. It derives its guidance from the rules and principles of Islam. It provides the concept of sharing between the enterprises and utilizes the funds on a profit and loss sharing basis. Islamic financing globally increase its size to make an agenda to save people from the pest of inflation that is a vital part of capitalism. The Holy Qur'an has clearly warned that those who do not forego interest which has already accrued and do not desist from taking it any further, then they are at war path with Allah and his Prophet (2:278279). Islamic Banking industry has shown tremendous growth. Study concludes that the western countries have also recognized the potential of Islamic financing industry and now opening the separate window in their countries. (Noor Ahmed Memon, 2007),

Suggested in this paper "differences and similarities in Islamic and conventional in banks". This research paper is conducted in Pakistan. Before some years Islamic bank popularity was not so much but now popularity of Islamic financing is increase as compare to conventional banking. Islamic banking is different as compare to conventional banking. According to this research paper Islamic banks are gain lot of profit in the Pakistan from last 6.5 years. So in this research paper Islamic banking play a central role in Pakistan as compare to conventional bank. (Hanif, 2011)

Suggested that the "financial performance on Islamic and conventional banks in Pakistan "a comparative study. There are 6 Islamic banks and 5 conventional banks taking as a sample size in this research paper. Ansari and Rehman present the realities of conventional and Islamic banks. They said Islamic banks are safer than conventional banks. Because Islamic banks does not depends on financial institutions loans. Due to this popularity Islamic banks are now prominent in the western countries as well. Islamic banking institution performs better as compare to the conventional banking sector in current state.( Ansari)

Recommend in "risk management in Islamic and conventional banks" in the business. Islamic finance customer takes a more risk as compare to the conventional finance because profit and loss include in Islamic finance institutions. In the conventional banking sector risk factor does not include because everything is fixed but in Islamic bank risk factor is the part of the agreement between customer and Islamic institutions. So according to the Shariah concepts Islamic finance is more profitable as compare the conventional bank .we can say that high risk high reward low risk low reward. (Sheik,2008)

"Islamic banking: a study of customer satisfaction and preferences in Jordan. The purpose of the research paper is to show the world that how the Islamic financing system gaining the momentum. The study took place in Jordan and 206 correspondents took the part in the study. Most of the people in Jordan have well idea about the products which the Islamic bank is offered. In this study, an attempt is made to assess the degree of customer awareness and satisfaction towards an Islamic bank in Jordan. The letter writer shows their certain degree of satisfaction of many of the Islamic banks facilities and products and also dissatisfaction with some of the Islamic products. The research paper shows that most of the peoples in Jordan are satisfied the Islamic banking and prefer Islamic banking on conventional. (Kamal Naser, 1999)

Compression of performance between two banking styles for Islamic and conventional in Gulf countries. With using quantities techniques and evidence Hadeel Abu Loghod suggest that there is no significant difference of profitability of both the banking sector in Gulf countries. About to this paper the conventional banks had less chance to liquidate. Or we can say they are less exposed to risk of liquidate. Internal growth of both the banks is almost same however it's all depend on the management style of a specific bank. (Hadeel Abu Loghod, 2005) 
This paper describes to determine the primary causes of financial crises that occur in every country around the world over the last 3 decades. One major cause that was found is the lack of adequate market discipline in the financial system. Lack of discipline leads the market to the excessive lending and highly leverages. Islamic finance inject the greater regulation in to the market and also condense the financial instability through risk sharing, restriction on sale of debt, short sale, gambling, excessive uncertainty and availability of credit for the purchase of goods and services. (M. Umer Chapra, 2008)

Financial crises comprise stock market crashes, currency crises sovereign defaults and financial bubbles. Financial crises generally linked to lack of adequate market discipline, greed and corruption, swindle, ordinarily high liquidity, speculation, breakdown between lender and borrower relationships, lack of transparency in asset pricing market. These crises have not occurred under the Islamic financial system because those factors who lead the crises are not allowed under the rules and guidance of Shariah. Islamic financial service industry presents more reliable alternative to the conventional financial system. (M. Kabir Hassan)

Global financial crises have badly affected the conventional banking system everywhere in the world. Performance of Islamic financial system is better than the conventional banking system in the global financial crises. Due to interest free nature of Islamic financial system the threat of it is very less than the conventional banking system. Study indicates that demand of Islamic financing system is increasing in the Western world due to global financial system. The research paper tests the validity of the view that in global financial crises Islamic banking system is more stable than the conventional banking system. They study shows that Islam is much more than the prohibition of Riba and Zakah, but a broad system to fulfill society's basic requirements. Islam focuses on people and their desires, rather than

production. (Azam Shafique,2008)

Media has given the name of financial crises to credit crunch or credit crises in beginning of August 2007. Liquidity crises occur in united state when investor loss a confidence in the value of securitized mortgages. These type of crises encouraged to a substantial injection of capital. We deviate from our philosophy or assumption that is growth tool for long term benefit and society welfare and now to serve the new target we follow the short term gains through the orientation of financial innovations and laxity of regulations. Islam is a religion that can never be allow to misuse of it. Islam considers a standard that is used to judge the performance of financial product before its introduction in to the market. In the current scenario Islamic financing has gained a massive attractiveness among all over the world as an alternative to avoid the credit crunch. (Ayman Zerban,2012)

The reason of global financial crises that hit the developed countries all over the world was debt securitization. Derivative instruments that are used in this process are not backed by real assets. Real economy sector cannot be developed by using these types of derivative instruments but it makes worst condition by making the bubble economic. This situation can be more harmful if the securitized debts are defaults. Islam had forbidden this practice very strictly. Islam has provided us the tools that are used to avoid the risk. This research paper try to examined the reasons of global financial crises and provide its solution through Islamic financing. (Miranti Kartika Dewi)

\section{Hypotheses}

$\mathbf{H}_{\mathbf{1}}$ : Islamic banks are more profitable than Conventional banks.

$\mathbf{H}_{2:}$ Islamic banks liquidity is higher than conventional banks.

$\mathbf{H}_{3:}$ : Islamic banks are less risky than Conventional banks.

$\mathbf{H}_{4:}$ Islamic banks are well capitalized than Conventional banks. 


\section{Hypothetical Framework}

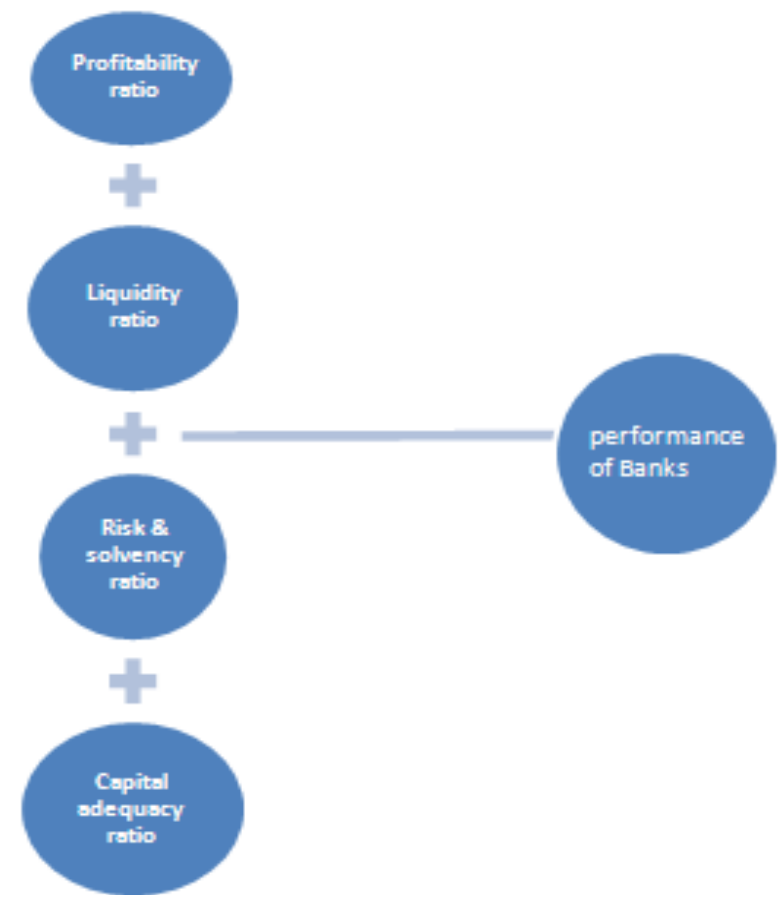

\section{Methodology}

\section{(5.1) Theoretical Framework}

The ratio analysis involves method of calculating and interpreting financial ratios to check the bank performance. Financial ratios are the signal of financial recital of bank. In order to compare performance of Islamic banks and Conventional banks for the era of 2008-2011 the study uses inter-bank analysis. The study evaluates inter-bank performance of Islamic and Conventional banks in term of risk profitability, liquidity, solvency and capital adequacy. Financial ratios are functional to measure these performances. These ratios are grouped under four broad categories.

\section{Profitability Ratios \\ 2. Liquidity Ratios \\ 3. Risk and Solvency Ratios \\ 4. Capital Adequacy Ratios}

\section{(5.1.1) Profitability Ratio}

How good is a company at running its business? Does its performance give the impression to be getting better or worse? Is it making any money? How profitable is it compared with its competitors? All of these very important questions can be answered by analyzing profitability ratios. Sammad and Hassan (1999) used three profitability ratios to evaluate the performance of Islamic bank Malaysia. These ratios were Return on average assets (ROAA) and Return on average equity (ROAE). This study uses the same Profitability measure to analyze the performance of banks in Pakistan.

Return on average assets $($ ROAA $)=$ Earnings after tax/Average assets

Return on average equity $($ ROAE $)=$ Earnings after tax/Average equity

\section{(5.1.2) Liquidity Ratio}

It is a class of financial metrics that is used to determine a company's ability to pay off its short-terms debts obligations. Generally, the higher the value of the ratio, the larger margin of safety that the company possesses to cover short-term debts. Samad \& Hassan (1999) used two more measures which include 
Loan/deposit ratio (LDR) and Current asset ratio (CAR) to evaluate the performance of Malaysian Islamic bank during 1984-1987. Hassan \& Bashir (2003) also used Net loans/ total assets ratio as liquidity measurement indicator. Liquidity position of banks in Pakistan is measured by using four above ratios.

$>$ Current Ratio $(\mathbf{C R})=$ Cash and account with banks/Total deposits

$>$ Current Asset Ratio $(\mathbf{C A R})=$ Current asset $/$ Total asset

$>$ Loan Deposit Ratio $($ LDR $)=$ Loans $/$ Deposits

$>$ Net Loan/ Total Asset Ratio (NLTA) $=$ Net loans/Total assets

\section{(5.1.3) RISK AND SOLVENCY RATIO}

Solvency ratios are one of the several tools used to measure the ability of a business to meet its longterm financial obligations. Essentially, this process calls for determining the total income generated by a business, Solvency ratios give a picture of a bank's ability to generate cash flow and pay its long-term financial obligations. If the total value of bank assets is greater than its equity then the bank is solvent. Samad \& Hassan (1999), Sanaullah Ansari \& Atiqa Rehman used three risks and solvency ratios in their study. Risk and solvency position of bank in Pakistan is measured by using following formulas.

$>$ Debt Equity Ratio $($ DER $)=$ Total Debt $/$ Shareholder Equity

$>$ Debt to total asset ratio $($ DTAR $)=$ Total Debt $/$ Total asset

$>$ Loan Deposit Ratio $($ LDR $)=$ Loans $/$ deposits

\section{(5.1.4) Capital Adequecy Ratio}

This ratio is used to protect depositors and promote the stability and efficiency of financial systems around the world. It is used to measure a bank's ability to meet its obligations relative to its exposure to risk. The capital adequacy ratio exists to ensure that a bank is able to handle losses and fulfill its obligations to account holders without ceasing operations. Adverse trends in these ratios may increase risk exposure and capital adequacy problems. Iqbal (2001) used Capital Asset Ratio (CAR) as capital adequacy measure. Hassan \& Bashir (2003) in addition to CAR used Equity/Liabilities ratio to measure capital adequacy in their study. This study focused on two following Capital ratios.

$>$ Equity/Liabilities ratio $=$ Average equity/ Average liabilities

$>$ Capital Risk Asset ratio = Total Capital/Risk weighted Assets

\section{(5.2) Population}

The population of this research is Islamic and conventional banks of Pakistan.

\section{(5.2.1) SAMPLE}

\section{Islamic banks Sample}

- Burj Islamic bank limited.

- Al Habib bank limited.

- Al Baraka Islamic bank.

- Dubai Islamic bank Pakistan limited.

\section{Conventional banks sample}

- Askari commercial bank limited

- Silk bank limited.

- KASAB bank limited.

- Meezan bank limited.

\section{(5.2.2) Data source}

The Audited financial statements i.e. Income Statement and Balance Sheet of both Islamic and Conventional banks for the period of 2008 -2011 are used for ratio analysis. The ratios have been calculated with the help of ratio formulas. The other sources used for data collection are SBP and business recorder databases.

\section{(5.3) Data Analysis}

T-test and ANOVA is used to conclude the significance of mean differences of these ratios between and among banks. The decision criterion is $\mathrm{P}$ value. If $\mathrm{P}$ value is greater than 0.05 we will accept null hypothesis and reject other hypothesis. The t-test compares the actual difference between two means in relation to the variation in the data (expressed as the standard deviation of the difference between the means). It is important to 
choose financial ratios that are applicable to the business at hand. There are hundreds of financial ratios available, some of which apply to all businesses and some of which are industry-specific.

\section{Data Finding, Analysis And Discussion}

This research paper analyzes and discusses the results that obtained from financial ratios, Independent sample t-test and ANOVA is also used. The equality of means of banks is tested through Independent sample ttest and ANOVA. T-test is used to make sure the significance of mean differences between banks and ANOVA is used to check the significance of mean differences among banks. Annova is most powerful statistic tool and process that is useful to analyze the variance between any numbers of samples.

Profitability of banks is analyzed by using two profitability measures ROAA and ROAE. ROAA is the net earnings per unit of a given asset. ROAE is the net earnings of per dollar equity capital, which analyzes the bank efficiency of making higher profits with given expense. Results show a fluctuating situation in all the profitability measures of banks from 2008-2011. It is analyzed from these figures that the profitability of both banks has increase, decrease trends. Average profitability ratios ROAA and ROAE for Islamic bank are .0033 and .2326 compared to -0.0117 and- 0.0116 for Conventional banks. T-test shows that this difference in profitability performance of Islamic banks is significant at $5 \%$ level of significance but not for conventional. However, ANOVA does not showing significance between the ROAE and PEM of banks from 2007-2011. Table \# 1

\begin{tabular}{|c|c|c|c|c|c|c|}
\hline \multicolumn{7}{|c|}{ T.test of Return on Arerage Assets (ROAH) } \\
\hline Banls Ratio & $2008 \quad 2009$ & 2010 & 2011 & Mean $\quad$ SD & t-value & $\begin{array}{l}\text { Pralue } \\
\text { Prol }\end{array}$ \\
\hline IBROAA & $\cdot 0.002 \quad 0.003712$ & .0 .01171 & 0.013289 & $0.0033 \quad .00702$ & & \\
\hline CBROAH & $-0.01168-0.002553$ & 0.01022 & 0.000043 & -0.0117 & .895 & .400 \\
\hline
\end{tabular}

ANNOVA of Return on Average Assets

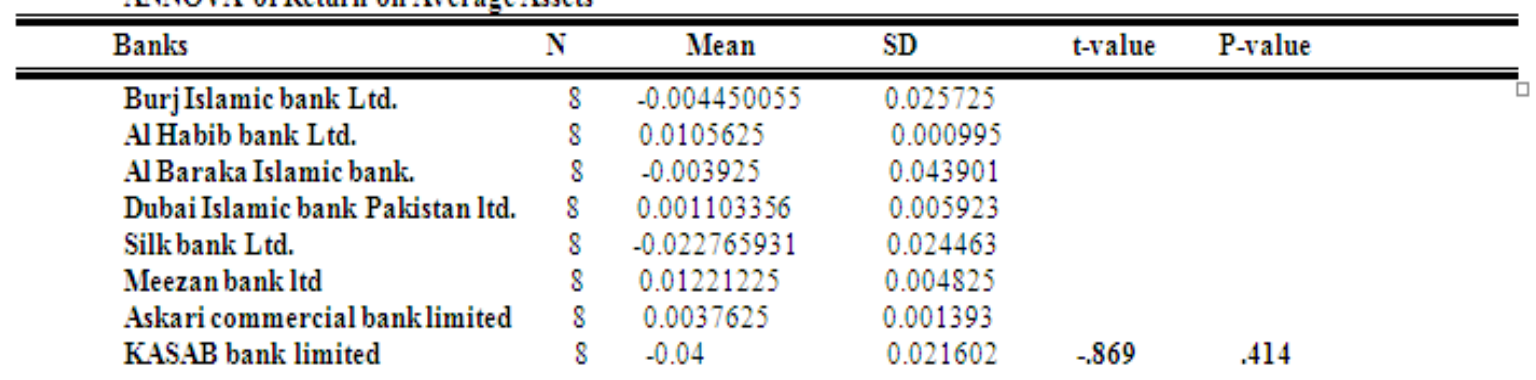

Table $=2$

\begin{tabular}{|c|c|c|c|c|c|c|c|c|}
\hline \multicolumn{9}{|c|}{ T-test of Return on Average Equity(ROAE) } \\
\hline Banks Ratios & 2008 & 2009 & 2010 & 2011 & Mean & SD & t-value & P-value \\
\hline IB ROAE & -0.01956 & 0.074755 & 0.01879 & 0.884528 & .2396 & .43167 & & \\
\hline CB ROAE & -0.09561 & -0.02553 & -0.01096 & 0.085887 & -0.0116 & .07473 & 1.019 & .342 \\
\hline
\end{tabular}


ANOVA of Return on Average Equity

\begin{tabular}{llllll}
\hline \hline & & & & & \\
Banks & N & Mean & SD & t-value & P-value \\
\hline \hline & & & & & \\
Burj Islamic bank Ltd. & 8 & -0.019893 & 0.073418 & & \\
Al Habib bank Ltd. & 8 & 1.04643 & 1.649665 & & \\
Al Baraka Islamic bank. & 8 & -0.07595 & 0.088496 & & \\
Dubai Islamic bank Pakistan ltd. & 8 & 0.007928 & 0.030754 & & \\
Silk bank Ltd. & 8 & -0.157655 & 0.16538 & & \\
Meezan bank ltd & 8 & 0.216975 & 0.109877 & & \\
Askari commercial banklimited & 8 & 0.07747 & 0.031962 & & \\
KASAB bank limited & 8 & -0.183 & 0.113531 & -1.473 & .194
\end{tabular}

Overall result shows that profitability performance of Islamic bank is significantly different from the performance of Conventional banks so research hypothesis is accepted that Islamic banks are more profitable than conventional banks.

The liquidity position of Islamic and Conventional bank is analyzed through Current ratio, Current Asset ratio, Loan Deposit ratio and Net Loans to Total Asset ratio. CR indicates the bank ability to meet its current liabilities. A higher value of $\mathbf{C R}$ shows that the bank has more liquid assets to pay back to its depositors CAR indicates the percentage of bank liquid assets. A high CAR is sign of liquidity. LDR measure the degree of bank relines on borrowed funds. The high figure of LDR shows that bank is more relying on borrowed funds and leads to illiquidity. Net loans to total assets ratio measures the total loans outstanding as a percentage of total assets. The higher this ratio indicates that a bank is loaned up and its liquidity is low. Sanaullah Ansari \&Atiqa Rehman (?)

Table \# 3

\begin{tabular}{|c|c|c|c|c|c|c|c|c|c|c|}
\hline \multicolumn{11}{|c|}{ T-test of current ratio } \\
\hline $\begin{array}{l}\text { Banks } \\
\text { value }\end{array}$ & Ratios & 2008 & 2009 & 2010 & 2011 & & Mean & SD & t-value & P- \\
\hline IB & CR & .13512 & .14213 & .16434 & .16064 & .1506 & .0 & & & \\
\hline $\begin{array}{l}\text { CB } \\
0.000\end{array}$ & CR & .10785 & .114343 & .12532 & .13286 & & .1201 & .01112 & 19.035 & \\
\hline
\end{tabular}

ANNOVA of Current Ratio

\begin{tabular}{|c|c|c|c|c|c|c|c|c|}
\hline \multicolumn{3}{|l|}{ Banks } & $\mathbf{N}$ & Mean & \multicolumn{2}{|l|}{ SD } & t-value & P-value \\
\hline \multicolumn{3}{|c|}{ Burj Islamic bank Ltd. } & 8 & 0.4346 & \multicolumn{2}{|c|}{0.599623} & & \\
\hline \multicolumn{3}{|c|}{ Al Habib bank Ltd. } & 8 & 0.097760 & \multicolumn{2}{|c|}{0.09621} & & \\
\hline \multicolumn{3}{|c|}{ Al Baraka Islamic bank. } & 8 & 0.170375 & \multicolumn{2}{|c|}{0.058591} & & \\
\hline \multicolumn{3}{|c|}{ Dubai Islamic bank Pakistan ltd. } & 8 & 0.188974 & \multicolumn{2}{|c|}{0.050343} & & \\
\hline \multicolumn{3}{|c|}{ Silk bank Ltd. } & 8 & 0.069742 & \multicolumn{2}{|c|}{0.007201} & & \\
\hline \multicolumn{3}{|c|}{ Meezan bank ltd } & 8 & 0.37905 & \multicolumn{2}{|c|}{0.537208} & & \\
\hline \multicolumn{3}{|c|}{ Askari commercial bankltd } & 8 & 0.11709 & \multicolumn{2}{|c|}{0.01394} & & \\
\hline \multicolumn{3}{|c|}{$\begin{array}{l}\text { KASAB bank limited } \\
\text { Table }=4\end{array}$} & 8 & 0.11 & \multicolumn{2}{|c|}{0.09561} & 3.860 & .008 \\
\hline \multicolumn{9}{|c|}{ T-test of current assets ratio } \\
\hline \multicolumn{2}{|c|}{$\begin{array}{l}\text { Banks Ratios } \\
\text { P-value } \\
\end{array}$} & 2008 & 2009 & 2010 & 2011 & Me: & SD & t-value \\
\hline IB & CAR & .15312 & 16713 & .15634 & .14564 & .1646 & .01416 & \\
\hline $\begin{array}{l}\text { CB } \\
0.000\end{array}$ & CAR & .08785 & .094343 & .33532 & .13286 & .1301 & .01112 & 19.035 \\
\hline
\end{tabular}


ANNOVA of Current Assets Ratio

\begin{tabular}{lcllll}
\hline \hline Banks & N & \multicolumn{1}{c}{ Mean } & SD & t-value & P-value \\
\hline \hline Burj Islamic bank Ltd. & 8 & 0.156481111 & 0.180641 & & \\
Al Habib bank Ltd. & 8 & 0.08228 & 0.107571 & & \\
Al Baraka Islamic bank. & 8 & 0.1751 & 0.032985 & \\
Dubai Islamic bank Pakistan ltd. & 8 & 0.188387192 & 0.017339 & & \\
Silk bank Ltd. & 8 & 0.081493608 & 0.0628209 & & \\
Meezan bank ltd & 8 & 0.1287775 & .024331 & & \\
Askari commercial bank limited & 8 & 0.133275 & .022033 & \multirow{2}{*}{$\mathbf{5 7 9}$} & .036 \\
KASAB bank limited & 8 & 0.10825 & .526023 & &
\end{tabular}

Table $=5$

T-test of loan deposit ratio

\begin{tabular}{|c|c|c|c|c|c|c|c|c|c|}
\hline $\mathrm{BaI}$ & Ratios & 2008 & 2009 & 2010 & 2011 & Mean & SD & t-value & P-value \\
\hline IB & LDR & 1.0390 & 1.0212 & 1.1111 & 1.0589 & 1.0578 & .03921 & & \\
\hline $\mathrm{CB}$ & LDR & .9182 & 1.2256 & 1.1802 & 1.16588 & 1.1225 & .13853 & 30.71 & .000 \\
\hline
\end{tabular}

ANNOVA Of Loan Deposit Ratio.

\begin{tabular}{llllll}
\hline \hline Banks & N & \multicolumn{1}{c}{ Mean } & \multicolumn{1}{c}{ SD } & t-value & P-value \\
\hline \hline Burj Islamic bank Ltd. & 8 & 0.912116 & 0.180641 & & \\
Al Habib bank Ltd. & 8 & 1.1496875 & 0.107571 & & \\
Al Baraka Islamic bank. & 8 & 1.10045 & 0.032985 & & \\
Dubai Islamic bank Pakistan ltd. & 8 & 0.847543 & 0.017339 & & \\
Silkbank Ltd. & 8 & 1.285148 & 0.0628209 & & \\
Meezan bank ltd & 8 & 1.11745 & 0.024331 & & \\
Askari commercial banklimited & 8 & 1.149925 & 0.022033 & & \\
KASAB bank limited & 8 & 0.905 & 0.526023 & 14.31 & .000
\end{tabular}

Table $=6$

T-test of Net Loan to Total Assets Ratio (NL/AR)

\begin{tabular}{lccccccccc}
\hline \multicolumn{2}{l}{ Banks Ratios } & $\mathbf{2 0 0 8}$ & $\mathbf{2 0 0 9}$ & $\mathbf{2 0 1 0}$ & $\mathbf{2 0 1 1}$ & Mean & SD & t-value & P-value \\
\hline IB & NL/DR & 1.10045 & 1.068862 & 1.14968 & 0.91217 & 1.1225 & 0.15839 & & \\
& & & & & & & & & \\
CB & NL/DR & 1.28514 & 1.149925 & 1.49225 & 0.905 & 1.0578 & .10265 & 16.669 & .000 \\
\hline
\end{tabular}

ANNOVA of Net Loan/ Deposit Ratio

\begin{tabular}{|c|c|c|c|c|c|}
\hline Banks & $\mathrm{N}$ & Mean & SD & t-value & P-value \\
\hline Burj Islamic bank Ltd. & 8 & 0.58542 & .217828 & & \\
\hline Al Habib bank Ltd. & 8 & 0.9432 & .00626 & & \\
\hline Al Baraka Islamic bank. & 8 & 0.8 & $.66 \quad .072887$ & & \\
\hline Dubai Islamic bank Pakistan ltd. & 8 & 0.84754 & .017339 & & \\
\hline Silkbank Ltd. & 8 & 0.94165 & .02289826 & & \\
\hline Meezan bank ltd & 8 & 0.928875 & .002232 & & \\
\hline Askari commercial bank limited & 8 & 0.94388 & .005778 & & \\
\hline KASAB bank limited & 8 & 0.91 & .06378 & 17.48 & .000 \\
\hline
\end{tabular}


Result shows that there is positive trend in CR and CAR of Islamic banks while LDR and NL/TAR ratio volatiles. There is rise and fall condition in all the liquidity measure of Conventional banks. However the values of CR and CAR are higher for Islamic bank whole selected period. This shows that Islamic bank has more liquid asset to meet its current liabilities. Islamic bank average CR and CAR are .1506 and .1646 as compared to .1201 and .1301 for Conventional banks and this mean difference is statistically significant at $1 \%$ level of significance.

Islamic bank average LDR and NL/TA ratio are 1.057 and 1.122as compared to 1.1225 and 1.0578 for Conventional banks. This mean difference between two banks is also significant at $5 \%$ level of significance. ANOVA shows significant mean difference in LDR and NLTA ratio of banks at $1 \%$.LDR and NL/TA ratio are in the favor of Islamic banks. These ratios are lower for Islamic banks, the lower these ratios it is considered better. These ratios show that Islamic banks do not rely more on borrowed funds and their percentage of assets occupied in loan is lower than conventional banks. Overall results of liquidity ratios support the hypothesis that Islamic banks are more liquid than conventional banks.

Three Risk and solvency measure DER, DTAR and LDR have been used to evaluate the riskiness of banks. DER measures the bank ability to absorb financial shocks. DTAR is the indicator of bank financial strength to pay its debtors.

\section{Table \# 7}

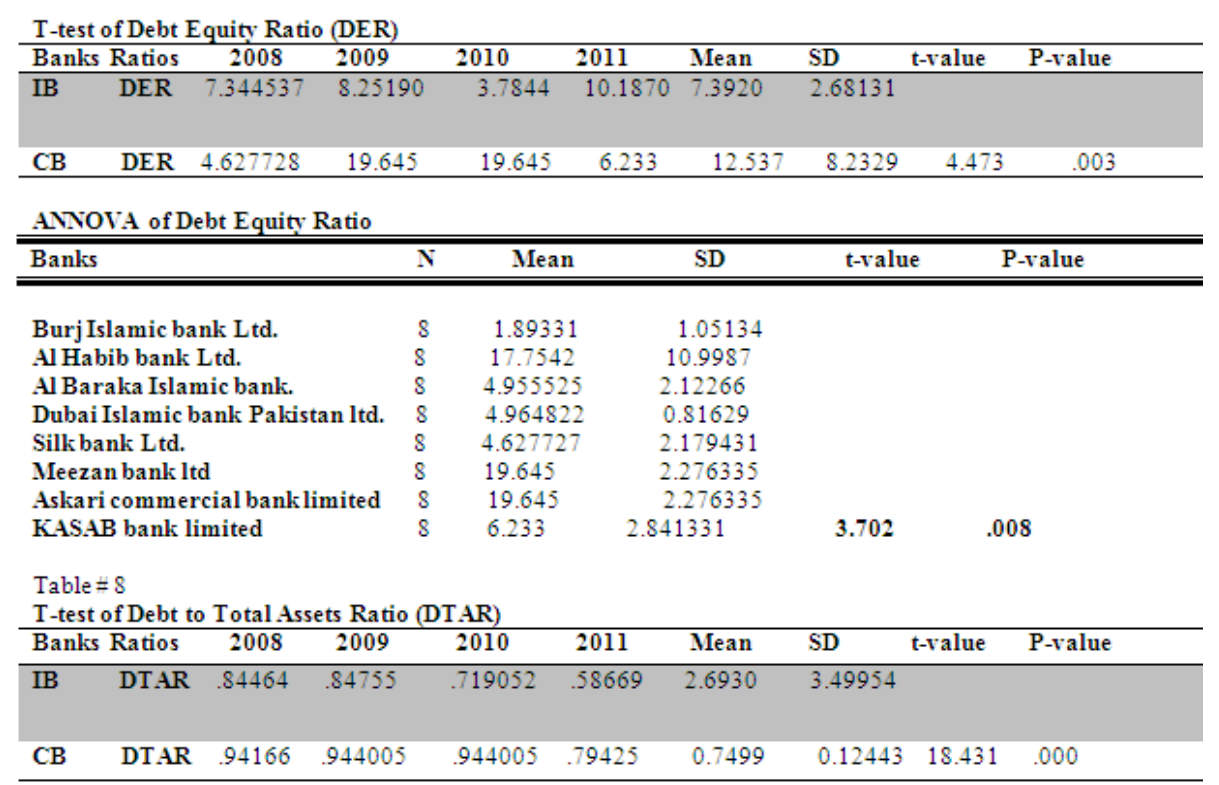

ANNOVA of Debt to Total Assets Ratio.

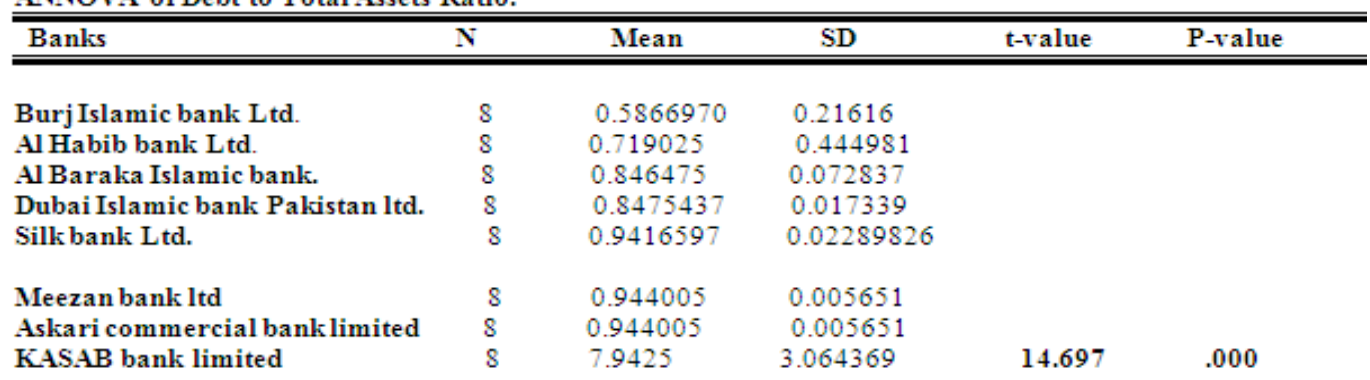

Table $=9$

\begin{tabular}{|c|c|c|c|c|c|c|c|c|c|}
\hline \multicolumn{2}{|c|}{ Banks Ratios } & 2008 & 2009 & 2010 & 2011 & Mean & $\mathrm{SD}$ & t-value & P-value \\
\hline IB & LDR & 1.0390 & 1.0212 & 1.1111 & 1.0589 & 1.0578 & .03921 & & \\
\hline $\mathrm{CB}$ & LDR & .9182 & 1.2256 & 1.1802 & 1.16588 & 1.1225 & .13853 & 30.71 & .000 \\
\hline
\end{tabular}


ANNOVA Of Loan Deposit Ratio.

\begin{tabular}{lclccc}
\hline Banks & N & Mean & SD & t-value & P-value \\
\hline \hline Burj Islamic bank Ltd. & 8 & 0.912116 & 0.180641 & & \\
Al Habib bank Ltd. & 8 & 1.1496875 & 0.107571 & & \\
Al Baraka Islamic bank. & 8 & 1.10045 & 0.032985 & & \\
Dubai Islamic bank Pakistan ltd. & 8 & 0.847543 & 0.017339 & & \\
Silk bank Ltd. & 8 & 1.285148 & 0.0628209 & & \\
Meezan bank ltd & 8 & 1.11745 & 0.024331 & & $\mathbf{0 0 0}$ \\
Askari commercial bank limited & 8 & 1.149925 & 0.022033 & $\mathbf{1 4 . 3 1}$ & $\mathbf{. 0 0 0}$ \\
KASAB bank limited & 8 & 0.905 & 0.526023 &
\end{tabular}

Average DER, DTAR and LDR for Islamic bank are 7.3920, 2.6930 and 1.0578 as compared to 12.537, 6.7499 and 1.1225 for their Conventional counterpart. Independent Sample t-test and ANOVA supports that the mean difference of DER and DTAR is statistically significant at 5\% level of significance. The lower risk and solvency ratios are good and show low riskiness of bank. All risk and solvency indicator shows lower percentage of risk for Islamic banks as compared to Conventional banks. It is analyzed from these results that Islamic bank are less risky than Conventional banks. Capital Adequacy Ratio (CAR), also called Capital to Risk (Weighted) Assets Ratio (CRAR). Capital adequacy ratios (CARs) is used to measure of the amount of a bank's core capital expressed as a percentage of its risk-weighted asset Table \# 10

T-test of equity/liability ratio

\begin{tabular}{lccccccccc}
\hline Banks Ratios & 2008 & 2009 & 2010 & 2011 & Mean & SD & t-value & P-value \\
IB & ELR & .4637 & .24451 & .2283 & .15822 & .2737 & .13212 & &
\end{tabular}

\begin{tabular}{llllllllll} 
CB & ELR & .3568 & .4600 & .1357 & .1568 & .15822 & .2774 & 5.793 & .001 \\
\hline
\end{tabular}

ANNOVA Of Equity To liability Ratio

\begin{tabular}{llccc}
\hline $\begin{array}{l}\text { Banks } \\
\text { value }\end{array}$ & N & Mean & SD & t-value \\
\hline \hline
\end{tabular}

Burj Islamic bank Ltd. Al Habib bank Ltd.

Al Baraka Islamic bank. Dubai Islamic bank Pakistan ltd 8 Silk bank Ltd.

Meezan bank Itd

Askari commercial bank limited 8

KASAB bank limited

$\begin{array}{lll}8 & 0.614201 & 0.348893 \\ 8 & 0.042965 & 0.003237 \\ 8 & 0.26925 & 0.125678 \\ 8 & 0.16847 & 0.078732 \\ 8 & 0.228516 & 0.0988438 \\ 8 & 0.2566 & 0.272906 \\ 8 & 0.2566 & 0.272906 \\ 8 & 0.36775 & 0.405451\end{array}$

4.708

.002

Table \# 11

T-test of capital risk asset ratio

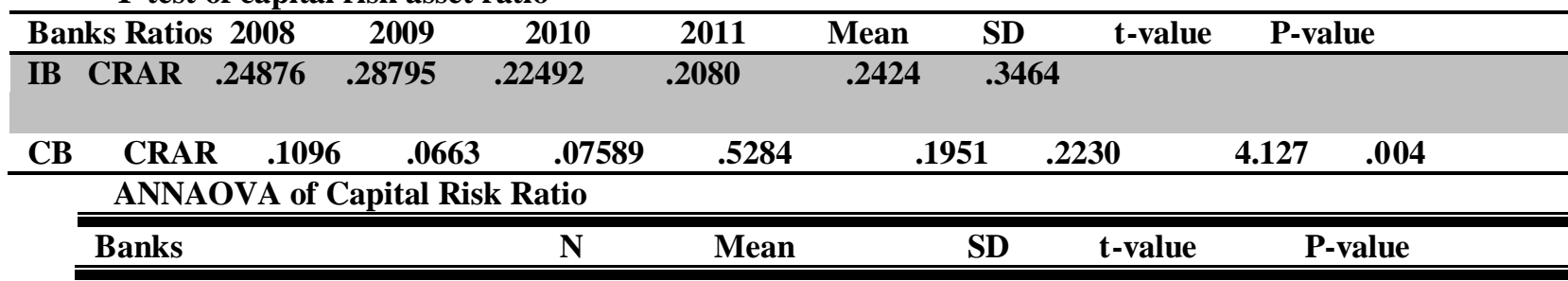

Burj Islamic bank Ltd.

Al Habib bank Ltd.

$\begin{array}{lll}8 & 0.4410477 & 0.053388 \\ 8 & 0.0592737 & 0.056219 \\ 8 & 0.2328597 & 0.062931 \\ 8 & 0.236520 & 0.02104 \\ 8 & 0.073895 & 0.02614523 \\ 8 & 0.311745 & 0.451205 \\ 8 & 0.311745 & 0.451205 \\ 8 & 0.0945 & 0.06028\end{array}$

Al Baraka Islamic bank. 
Capital adequacy of banks is deliberate with the help of Equity/Liability and Capital risk asset ratios. Islamic and Conventional bank capital adequacy ratios confirm increase and decrease trends. When average Capital ratios are compared for Islamic and Conventional banks it is analyzed that Islamic bank have higher Equity liability and lower Capital risk asset ratio than Conventional banks. Islamic bank average capital risk asset ratio and Equity liability ratios are .2424 and .2737 respectively while these ratios for Conventional banks are .1951 and .1582 respectively. T-test shows that there is high significant mean difference between these ratios at $\mathbf{5 \%}$ level; and ANOVA also supports significant mean difference among banks at both $\mathbf{5 \%}$ and $\mathbf{1 \%}$ level of significance. These results do not support the hypothesis that Islamic bank are better capitalized than their Conventional peers.

\section{Significance Of The Paper}

Financial Institutions are playing very imperative role in every economy because financial institutions has most causative factor that keep economies on the trail of economic welfare and development. Financial ratios are the indicator of financial position and health of organization. Ratio analysis is not only essential for depositors' point of view but it is also important for management to improve the financial health and future performance of the organization. Financial ratios illustrate the strengths and weaknesses of a business. By exploratory ratios after a while, a business owner can observe any abnormal fluctuations in financial ratios and can note how the business is performing in the end. Ratios are also helpful tools in financial analysis and forecasting; ratios permit the entrepreneurs to set specific goals and easily path to progress toward those goals. The purpose behind this research is to make people aware of Islamic banks financial position and to make assessment of financial health and performance of Islamic and Conventional banks in order to identify, which one has, better economic (financial) position.

\section{Conclusion}

A comparative study is conducted to examine the performance of Islamic and Conventional banks in Pakistan found that Islamic banks in Pakistan have better financial performance than their Conventional counterparts. . Results of profitability Ratio shows a fluctuating situation in all the profitability measures of banks from 2008-2011. It is analyzed from these figures that the profitability of both banks has increase, decrease trends. Average profitability ratios ROAA and ROAE for Islamic bank are .0033 and .2326 compared to -0.0117 and- 0.0116 for Conventional banks. The liquidity position of Islamic and Conventional bank is analyzed through Current ratio, Current Asset ratio, Loan Deposit ratio and Net Loans to Total Asset ratio. CR indicates the bank ability to meet its current liabilities. Result shows that there is positive trend in CR and CAR of Islamic banks while LDR and NL/TAR ratio volatiles. There is rise and fall condition in all the liquidity measure of Conventional banks. However the values of CR and CAR are higher for Islamic bank whole selected period. Islamic bank average LDR and NL/TA ratio are 1.057 and 1.122as compared to 1.1225 and 1.0578 for Conventional banks. This mean difference between two banks is also significant at $5 \%$ level of significance. ANOVA shows significant mean difference in LDR and NLTA ratio of banks at $1 \%$.LDR and NL/TA ratio are in the favor of Islamic banks. These ratios are lower for Islamic banks, the lower these ratios it is considered better. The result of risk and solvency ratio shows the Average DER, DTAR and LDR for Islamic bank are 7.3920, 2.6930 and 1.0578 as compared to $12.537,6.7499$ and 1.1225 for their Conventional counterpart. Independent Sample t-test and ANOVA supports that the mean difference of DER and DTAR is statistically significant at $5 \%$ level of significance. The lower risk and solvency ratios are good and show low riskiness of bank. All risk and solvency indicator shows lower percentage of risk for Islamic banks as compared to Conventional banks. Capital adequacy of banks is deliberate with the help of Equity/Liability and Capital risk asset ratios. Islamic and Conventional bank capital adequacy ratios confirm increase and decrease trends. When average Capital ratios are compared for Islamic and Conventional banks it is analyzed that Islamic bank have higher Equity liability and lower Capital risk asset ratio than Conventional banks. Islamic bank average capital risk asset ratio and Equity liability ratios are .2424 and .2737 respectively while these ratios for Conventional banks are .1951and .1582 respectively. T-test shows that there is high significant mean difference between these ratios at 5\% level; and ANOVA also supports significant mean difference among banks at both $\mathbf{5 \%}$ and $\mathbf{1 \%}$ level of significance. By the using of the data of (2008_2011) of eight banks of Pakistan, suggest that the Performance, Profitability of Islamic banking is higher as compare to conventional financing and low risk is facing by Islamic banking.

\section{Acknowledgement:}

Starting in the name of Allah the most merciful the most beneficial we would like to thanks Allah Almighty who gave us knowledge and courage and this assignment is completed. We would like to say thanks to our families and friends who really helped us in completing not only this project but at every step of life. Finally we would like to thanks our teachers specially (Zeeshan Arshad and M. Amer Saeed Butt) who taught us in way that would be very beneficial for us. 


\section{Suggestions For Further Research}

1. Sample size should be increased for the same study. More banks should be taken as a sample to generalize the result of study on the whole industry.

2. Since Islamic banking are in the introductory phase in Pakistan. There is a strong need to conduct Performance evaluation studies from time to time so that corrective actions may be taken accordingly

3. This research provides new avenues for future research. Finding of this study generate a lot of questions in researchers mind; e.g.

i. Why there is no difference between the profitability of two banks

ii. Why Islamic bank are more liquid than Conventional banks

iii. Why Islamic banks are less risky than Conventional banks

iv. Why operational efficiency of Islamic bank is better than Conventional banks.

\section{References}

[1]. Hanif.M (2011), "Differences and Similarities in Islamic and Conventional Banking" International Journal of Business and Social Science; $2(2)$

[2]. AHMED.B \& ABDERRAZAK.B (2010), “ISLAMIC FINANCE IN EUROPE: THE REGULATORY CHALLENGE”,Islamic Economic Studies; 17,2 .

[3]. Solé.J (2007), "Introducing Islamic Banks into Conventional Banking Systems". International Monetary Fund.

[4]. Aburime.U \& Alio.F (2009), "Islamic Banking: Theories, Practices and Insights For

[5]. Nigeria". International Review of Business Research Papers 5 (1), 321-33.

[6]. Mervyn K. Lewis, "In what ways does Islamic banking differ from conventional finance?"

[7]. Samad, A. and Hassan, M.K. (1999). "The Performance of Malaysian Islamic Bank during 1984-1997: An Exploratory Study". International Journal of Islamic Financial Services, 1(3).

[8]. Moin S.M. (2008), "Performance of Islamic Banking and Conventional Banking in Pakistan: A Comparative Study. Skovade: University of Skovade school of technology and society".

[9]. Chapra.U.M (Oct 2008), "THE GLOBAL FINANCIAL CRISIS: CAN ISLAMIC FINANCE HELP MINIMIZE THE SEVERITY AND FREQUENCY OF SUCH A CRISIS IN THE FUTURE?"

[10]. Ahmed.A "Global financial crisis: an Islamic finance perspective"

[11]. Ryu.P.K, Piao.Z.S, nami.D (May, 2012), "A Comparative Study between the Islamic and Conventional Banking Systems and Its Implications". Scholarly Journal of Business Administration 2(5), 48-54

[12]. Khan.A.Z (2009), "Growth of Islamic Banking in Pakistan. INSTITUTE OF BUSINESS AND TECHNOLOGY".

[13]. B.Jorg \& K.Kermit, "CONVENTIONAL VERSUS ISLAMIC FINANCE: STUDENT KNOWLEDGE AND PERCEPTION IN THE UNITED ARAB EMIRATES”.International Journal of Islamic Financial Services 5,pp.4

[14]. Siddiqui, S.A. (2005). "Understanding and Eliminating Riba: Can Islamic Financial Instruments Be Meaningfully Implemented?’Journal of Management and Social Sciences, 1(2), pp.187-203.

[15]. Aggarwal, Rajesh, K., \& Tarik, Y. (2000). “islamic Banks and Investment Financing.” Journal of Money, Banking, and Credit, 32(1), 93-120.

[16]. Mohieldin et al, "The Role of Islamic Finance in Enhancing Financial Inclusion in OIC Countries, 8th International Conference on Islamic Economics and Finance."

[17]. Hassan.K.M, Kayed.R, "The Global Financial Crisis and Islamic Finance,University of New Orleans, USA,Arab-American University, Palestine"

[18]. Awan.G.A (November 14, 2009), “COMPARISON OF ISLAMIC AND CONVENTIONAL BANKING IN PAKISTAN". Department of Economics, Islamia University, Bahawalpur-Pakistan.

[19]. Beck.T, Kunt.D.A, Merrouche.O, (2010)," Islamic vs. Conventional Banking Business Model, Efficiency and Stability"

[20]. Memon.A.N (2007), Islamic Banking: Present and Future Challenges, "Department of Economics, Institute of Business \& Technology (BIZTEK)", Journal of Management and Social Sciences, 3, No. 1, (Spring 2007) 01-10

[21]. Shafique.A, faheem.A.M, iqra (2008) "Impact of Global Financial Crises on the Islamic

[22]. Banking System, Analysis of Islamic Financial System during Financial Crunch 2008," Arabian Journal of Business and Management Review (OMAN Chapter), 1, No.9; April 2012

[23]. Zerban.A, Elkady.H. E,omar.F.R, “Islamic Finance and Global Financial Crises: How to Keep Finance on Track?", Topics in Middle Eastern and African Economies. 14, September 2012

[24]. Dewi.K.M, Ferdian.R.I, "Islamic Finance: A Therapy for Healing the Global Financial Crisis,"

[25]. Dubai Islamic bank financial reports .Retrieved February 8, 2013,from http://www.dibpak.com/AboutUs.aspx?tab=6

[26]. Al Baraka financial reports. Retrieved February 8, 2013, from http://www.albaraka.com.pk/investor-relation/financial-statements.php

[27]. Burj Bank limited financial reports. Retrieved February 8, 2013, from http://www.burjbankltd.com/about/financial-highlights

[28]. Bank AL Habib limited financial reports. Retrieved February 8, 2013, from https://www.bankalhabib.com/quicklinks/financialReport2012.php

[29]. KASB Bank limited financial reports. Retrieved February 8, 2013, from http://www.kasb.com/bank/downloads.aspx

[30]. Mezzan Bank limited financial reports. Retrieved February 8, 2013, from http://www.meezanbank.com/financialHighlights.aspx

[31]. Askari Bank limited financial reports. Retrieved February 8, 2013, from http://www.askaribank.com.pk/financial_report.php

[32]. Silk bank limited financial reports. Retrieved February 8, 2013, from http://www.silkbank.com.pk/index.php?option=com_content\&view=article\&id=39\&Itemid=36 